\title{
Звезды аналитического приборостроения Дэвид Паккард и Уильям Хьюлетт
}

Ю.А. Золотов

\begin{abstract}
Американский Фонд химического наследия (Chemical Heritage Foundation) в свое время подготовил и распространил на одной из Питтсбургских конференций по аналитической химии и прикладной спектроскопии (Pittcon) биографический материал о создателях крупнейших фирм, разрабатывающих и выпускающих аналитические приборы. Это компании Hewlett-Packard, Perkin-Elmer, Mettler, Varian, Beckman, Finnigan, Waters, Horiba и др. Часть этих компаний в настоящее время влились в другие, как, например, Finnigan, или разделились на части, как Hewlett-Packard. Предлагаем вниманию читателя серию статей, основанных на переводах некоторых материалов".
\end{abstract}

\section{ДЭВИД ПАККАРД}

Дэвид Паккард (1912-1996) родился в Пуэбло (штат Колорадо, США).

Получил степень бакалавра как электроинженер в 1934 году в Стэнфордском университете. Старался самоутвердиться в спорте: и в школе, и в университете получал призы как баскетболист и футболист.

В 1936-1938 годах Д. Паккард работал электроинженером в компании "Дженерал электрик" в Шенектеди (штат НьюЙорк).

В 1938 году возвратился в Стэнфорд и поступил в магистратуру. Здесь он подружился со студентом-инженером Уильямом Хьюлеттом. Имея капитал в 538 долларов, они решили наладить бизнес в гараже Д. Паккарда. Просто бросив монетку, друзья определили последовательность фамилий в названии новой фирмы (Хьюлетт-Паккард, НР), которое зарегистрировано было в 1947 году. Первое изделие компании - аудиоосциллятор, а среди первых его покупателей оказался Уолт Дисней.

Д. Паккард проявил себя выдающимся менеджером, под его руководством бизнес динамично развивался от аналитических приборов к компьютерам. К 1980-м годам на рынке компьютеров Хьюлетт-Паккард был уже гигантом. Помимо бизнеса, Паккард также уделял большое внимание политике. В период между 1969 и 1971 годами он служил заместителем министра обороны при президенте Ричарде Никсоне и участвовал в решении многих серьезных проблем, с которыми США сталкивались в это время, например в свертывании вьетнамской войны. В 1970-1980 годах он входил также в состав ряда президентских комиссий, а в 19901992 годах состоял членом комитета советников по науке и технологии при президенте Джордже Буше.

Статья из Кн. Ю. А. Золотова "Очерки истории аналитической химии" (М.: ТЕХНОСФЕРА, 2018) публикуется с некоторыми изменениями.
Деятельность Д. Паккарда получила широкое признание: он был избран членом Института инженеров-электриков и электронщиков, членом Национальной инженерной академии и Американского общества создателей приборов. Он был также соучредителем Американской электронной ассоциации.

В 1993 году Паккард покинул пост председателя совета директоров компании Хьюлетт-Паккард и до своей кончины в марте 1996 года оставался его почетным председателем.

\section{УИЛЬЯМ ХЬЮЛЕТт}

Уильям Хьюлетт (1913-2001) обладал многими талантами: он был ботаником, фермером, волонтером и выдающимся инженером, чей вклад в аналитическое приборостроение поистине неоценим. У.Хьюлетт родился в Энн-Арборе (штат Мичиган), получил степень бакалавра в Стэнфордском университете (где познакомился с Дэвидом Паккардом) и степень магистраэлектроинженера в Массачусетском технологическом институте. В 1938 году вернулся в Стэнфорд, чтобы получить следующую ученую степень как инженер, но отказался от этой идеи, поскольку вместе с партнером Д. Паккардом решил оставить науку ради бизнеса.

У. Хьюлетт хотел создать осциллятор, который был бы легким, портативным, простым по конструкции, но одновременно соединяющим в себе стабильность осциллятора типа конденсатора с обмоткой и гибкость осциллятора со стандартной частотой. Работая в гараже Д.Паккарда в Пало-Альто в Калифорнии, он создал совершенно оригинальный прибор, названный Model 200A. Это практическое устройство для интегрирования высококачественных частот стало первым в ряду многочисленных изделий фирмы Хьюлетт-Паккард. Уолт Дисней купил восемь аудиоосцилляторов для работы при производстве мультфильма "Фантазия", с их помощью тестировалась система стереозвука. 


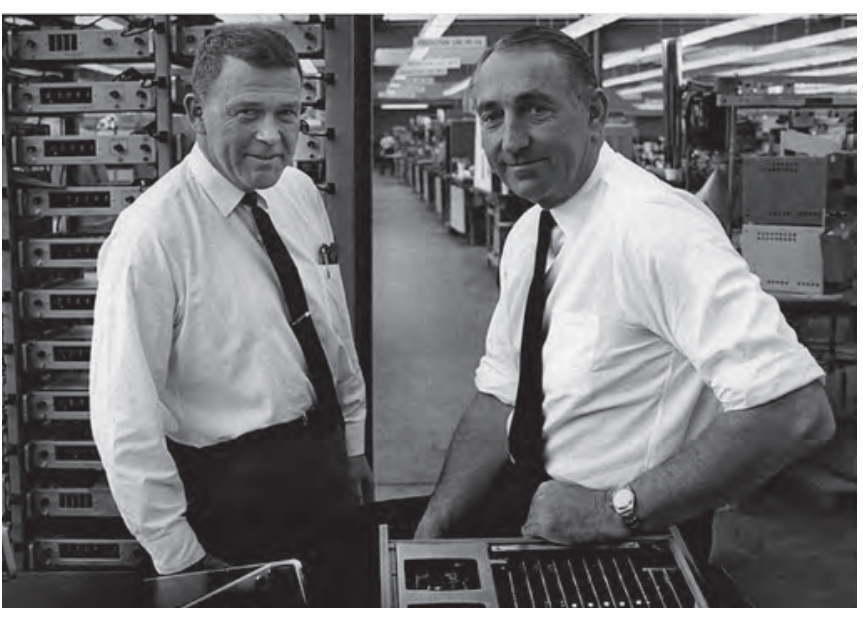

Слева направо: Дэвид Паккард и Уильям Хьюлетm

Во время Второй мировой войны У. Хьюлетт служил в команде главного офицера службы оповещения, а затем возглавлял секцию электроники специальной команды отдела новых разработок Министерства обороны. На этой должности он входил в состав группы, которая проводила инспекцию японской промышленности сразу после окончания войны. В 1947 году он возвратился в Калифорнию, снова стал работать в НР в качестве вице-президента компании. Когда через сорок лет он выходил в отставку, в послужном списке были должности вице-президента, президента, генерального директора, председателя исполнительного комитета и вице-председателя совета директоров.

У. Хьюлетт имел большое влияние в сфере образования, его считали также крупной фигурой во многих организациях электронной промышленности. Он был президентом Института радиоинженеров (позднее - Институт электроинженеров и инженеров электроники) и выполнял обязанности директора таких разных организаций, как Стэнфордский университет, госпиталь Фонда Кайзера и Совет по наркотикам.

Имел много почетных званий, включая членство в Национальной инженерной академии и Национальной академии наук, входил в состав Американской академии искусств и наук, Калифорнийской академии наук. В 1985 году президент Рональд Рейган вручил ему Национальную научную медаль.

Длительноепребывание Уильяма Хьюлетта и Дэвида Паккарда во главе компании способствовало тому, что фирма в своей области стала одной из самых крупных корпораций в мире.

\section{ИССЛЕДОВАТЕЛИ РАСКРЫЛИ ПРОИСХОЖДЕНИЕ И ХИМИЧЕСКИЙ СОСТАВ ТАИНСТВЕННЫХ ДЮН ТИТАНА}

Продольные дюны высотой до 100 м в экваториальных пустынях спутника Сатурна Титана являются наиболее монументальными поверхностными структурами Солнечной системы. Химический состав их органических веществ оставался тайной, а ацетиленовый лед, обнаруженный вблизи дюны, считался сырьем, из которого появились эти объекты. Серия лабораторных экспериментов исследователей из Гавайского университета продемонстрировала, что ароматические углеводороды - бензол, нафталин и фенантрен, как предполагаемые строительные блоки органического материала дюны - могут быть синтезированы из ацетиленового льда на поверхности Титана посредством воздействия космических лучей.

"Дюны Титана представляют собой доминирующий поверхностный сток углерода в органической химии Титана", - считает МэтьюАбпаналп из лаборатории астрономии им. М. Кека. «Поэтому, чтобы выяснить происхождение и химические пути формирования этого органического материала дюны, важно не только изучить химическую эволюциюТитана, но и понять, насколько похожи химические составы на Титане и Земле до появления жизни 3,5 млн лет назад". Ацетиленовый лед при низких температурах подвергался во3действию космических лучей высокой энергии. В результате простые молекулы ацетилена успешно преобразовались в более сложные органические молекулы.

Обнаружено, что полициклические ароматические углеводороды (ПАУ) (нафталин и фенантрен) вместе с прекурсорами (бензол, фенилацетилен, стирол) могут быть синтезированы с помощью космических лучей в низкотемпературные ацетиленовые льды на поверхности Титана и служить молекулярным сырьем для органического материала дюн. Это может привести к образованию молекулярных строительных блоков не только для органических дюн Титана, но и для органических веществ на безвоздушных телах, таких как объекты пояса Койпера или карликовая планета Makemake.

«Низкотемпературный синтез ПАУ из ацетиленовых льдов представляет собой расширение общепринятых представлений о том, что образование ПАУ происходит исключительно в газовой

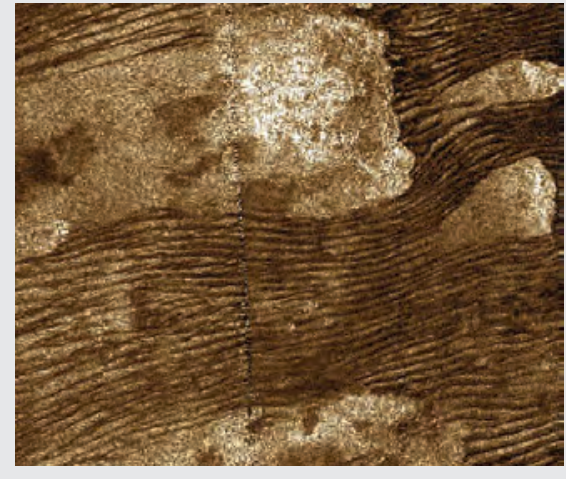

фазе в процессе сгорания при температурах в тысячи К».

Это углубляет понимание сложной органики и химической обработки простых молекул в глубоком космосе и дает научно обоснованный и проверенный механизм образования ароматических структур в экстремальных условиях в низкотемпературных льдах. Титан богат азотом, и включение его в ПАУ может привести к появлению углеродноазотных фрагментов, таких как азотистые основания на основе ДНК и РНК.

Источник: http://www.sci-news.com 